\title{
Implementation of an Integrated Floating Wetland and Biofilter for Water Treatment in Nile Tilapia Aquaculture
}

\author{
Somanas Somprasert ${ }^{1}$, Sattaya Mungkung ${ }^{1}$, Nathiya Kreetachat ${ }^{1}$, \\ Saksit Imman', Supreeda Homklin ${ }^{1 *}$ \\ 1 School of Energy and Environment, University of Phayao, 19, Moo 2, Maeka, Phayao, Thailand \\ * Corresponding author's e-mail: supreeda.ho@up.ac.th
}

\begin{abstract}
Due to the high nutrient and organic matter contents of fish pond water, the water must be treated before disposal to prevent the eutrophication and deterioration of natural receiving waters. Floating wetlands (FTWs) and biofilters are environmentally friendly ecological treatments that can be used for this water. Thus, this study aimed to investigate the performance of FTWs with biofilters (FTW/Bs) for nutrient and organic compound removal. Two FTW/ Bs were applied in a pond with 5,000 Nile tilapia. The macrophyte species in the FTWs were Cyperus (Cyperus spp.) and Heliconia (Heliconia spp.). The buoyant mats of the FTWs were made from bamboo, and 200 bioballs were loaded below the mats. The water quality parameters in the pond were monitored for 5 weeks between the control test without the FTW/Bs and the experimental test with FTW/Bs at sites 1 (S1) to 8 (S8). The FTW/Bs were located at sites 2 (S2) and 3 (S3). The results showed reductions in all water quality parameters except orthophosphate (ortho-P) at $\mathrm{S} 2$ and $\mathrm{S} 3$. The $\mathrm{COD}, \mathrm{BOD}, \mathrm{NH}_{4}-\mathrm{N}$, and $\mathrm{SS}$ at $\mathrm{S} 2$ and $\mathrm{S} 3$ parameters during the experimental test were significantly lower than those during the control test, in the ranges of 20.34-33.96, 25.47-29.41, 25.86-27.87, and 26.00-28.44\%, respectively.
\end{abstract}

Keywords: aquaculture, biofilter, fish pond water, floating wetland.

\section{INTRODUCTION}

Fishery farms are a source of wastewater with high nutrient and organic matter contents. Nile tilapia is an important species produced by aquaculture worldwide. The production of Nile tilapia was $70.3 \%$ higher in 2018 than in 2010 [FAO, 2020]. In Thailand, Nile tilapia fish farming has also been increasing due to the niche domestic and international markets for this fish. In practice, the water in fishponds must be withdrawn and discarded into natural receiving waters to control the concentrations of pollutants that are toxic to fish. The discarded wastewater can cause eutrophication and deterioration in the natural receiving waters. Constructed wetlands are an ecologically sound treatment technique for this wastewater because of their low cost and low maintenance requirements [Wu et al., 2015]. They contain the plant and bedding materials that remove nutrients, organic matter, and suspended solids from water. However, constructing these systems requires a large area [Borne et al., 2013]. Floating treatment wetlands (FTWs) are one type of wetland in which macrophytes grow on buoyant mats and float on surface water [Tanner and Headley, 2011, Castro-Castellon et al., 2016]. The macrophyte roots are suspended in and directly contact the water, which increases the nutrient uptake rate [Tanner and Headley, 2011]. FTWs not only drive nutrients to the macrophyte biomass but also increase contaminant decomposition and the filtration of suspended solids by plant roots [Tanner and Headley, 2011, Castro-Castellon et al., 2016]. The roots of the FTW plants provide oxygen through their axial tissues and secrete exudates that surround the rhizosphere to enhance the activity of microorganisms as well as the physical and biochemical reactions 
that damage pollutants [Bissegger et al., 2014, Pawlineri et al., 2017, Benvenuti et al., 2018]. FTWs do not require land for construction, have low investment and maintenance costs, and do not consume energy [Abed et al., 2017]. Moreover, they can be applied on fish farms due to their ability to move with the water level. Macrophytes are usually planted in FTWs, such as Iris pseudacorus L., Canna indica L., [Wu et al., 2016], Cyperus alternifolius [Zhang et al., 2014], Canna flaccida, and Juncus effusus [White and cousin, 2013]. The buoyant mats are made from various materials, such as PVC pipes, plastic mesh, foam, and bamboo [Pavlineri et al., 2017]. However, FTWs can be enhanced by adding substrates such as ceramsite and rice straw as well as biodegradable plastic [Cao et al., 2016, Lopardo et al., 2019] for use as carbon sources and for biofilm attachment. Biofilters are systems that contain bioballs to increase the surface area for biofilm attachment. Biofilms can support FTWs to increase the population of attached microorganisms and their efficiency at removing organic compounds from water. Wu et al. [2016] reported that plants coupled with fiber filters increased the COD removal by approximately $14.7 \%$ compared with the treatment with plants alone. The previous research has used this technique to treat nutrients and heavy metals in domestic sewage [Saeed et al., 2014, Benvenuti et al., 2018], stormwater [White and Cousins, 2013, Borne et al., 2013, Wang et al., 2014, Tharp et al., 2019], polluted rivers [Cao et al., 2016, Shahid et al., 2019], gray water [Abed et al., 2017], and agricultural runoff [Barco and Borin, 2020].

In Mungkung et al. [2017], FTWs were integrated with biofilters to treat the water from a Nile tilapia fish pond at the laboratory scale. The results showed that an FTW with a biofilter could reduce the TKN, TP, and BOD by approximately $81.64,41.50$, and $67.75 \%$, respectively, with a hydraulic retention time (HRT) of 7 days. In addition, in a control test without FTW and biofilters, TKN, TP, and BOD decreased by only 46.23 , 38.00 , and $27.75 \%$, respectively. Thus, this study aimed to investigate the performance of FTWs with biofilters (FTW/Bs) to remove nutrients and organic compounds from the fish pond water. The plants used in this study were a polyculture of Cyperus and Heliconia. The experiment was conducted at the pilot scale. The source of wastewater in this study was a Nile tilapia pond.

\section{METHODOLOGY}

\section{Site description}

The study site was an earthen Nile tilapia pond. The area of the pond was $1600 \mathrm{~m}^{2}(20 \mathrm{~m}$ x $80 \mathrm{~m}$ width and length)). Approximately 5,000 4-month-old Nile tilapia were cultured. The sampling points were located at 8 sites, from site 1 (S1) to site 8 (S8), as shown in Figure 1. Inside the fishpond, nine-blade turbines were installed at sites 6 (S6) and 7 (S7). This turbine was operated $6 \mathrm{hr}$ /day in both the control test (C) and the experimental test $(\mathrm{T})$. A water pump was installed at site 1 (S1), which was assumed to be in the inlet and outlet for the water in the fish pond. FTW/Bs were placed at sites 2 (S2) and 3 (S3).

\section{Experimental setup}

The two buoyant mats were made from bamboo, with an area of $0.9 \mathrm{~m}^{2} /$ mat $(0.6 \mathrm{~m} \mathrm{x} 1.5$ $\mathrm{m} \times 0.6 \mathrm{~m}$ width $\times$ length $\times$ depth), as shown in Figure 1. Seven Cyperus (Cyperus spp.) and Heliconia (Heliconia spp.) plants were placed on the top of each mat, and 200 bioballs were placed below. The surface area of the bioballs was 105 $\mathrm{m}^{2} / \mathrm{m}^{3}$. The plants and bioballs were acclimated to the fish pond water for two weeks before they were transferred to the buoyant mat to form the integrated floating wetlands and biofilters (FTW/ $\mathrm{Bs})$. The control test (C) was conducted without FTW/Bs, and the experimental tests $(\mathrm{T})$ were carried out with FTW/Bs. The FTW/B reactors were acclimated for 4 weeks before gathering the water samples. The water quality was monitored for 5 weeks. Both the control test and experimental test were performed in the same fish pond, but the experiments were conducted at different times.

\section{Water sampling and chemical analysis}

One liter water samples were collected in PE bottles. The $\mathrm{pH}$, temperature, dissolved oxygen (DO), chemical oxygen demand (COD), biological oxygen demand (BOD), total Kjeldahl nitrogen (TKN), ammonia nitrogen $\left(\mathrm{NH}_{4}-\mathrm{N}\right)$, orthophosphate (ortho-P), and suspended solids (SS) were measured. The $\mathrm{pH}$, temperature and DO were analyzed by a multimeter (PCD650, Eutech). The COD, BOD, TKN, $\mathrm{NH}_{4}-\mathrm{N}$, ortho-P, and SS were measured according to the standard methods [APHA, 2005]. All samples were measured with two replicates. 


\section{Statistical analysis}

All statistical analyses were conducted with Stata version 14.2 software (StataCorp LLC., Texas, USA). The differences in water qualities between the control test and experimental test were analyzed by one-way ANOVA with Duncan's post hoc test and were considered significant at the 0.05 level.

\section{RESULTS AND DISCUSSION}

\section{Physiochemical properties of wastewater from fish farms}

This study investigated the water quality in a fish pond with approximately 5,000 Nile tilapia per $1,600 \mathrm{~m}^{2}$. The results showed that the concentrations of COD, BOD, TKN, $\mathrm{NH}_{4}-\mathrm{N}$, ortho-P, and SS were in the ranges of $39.20-94.08,12.00-$ $63.40,5.60-24.64,3.36-17.92,0.04-0.13$, and $60.00-212.00 \mathrm{mg} / \mathrm{L}$, respectively. In practice, to maximize the growth of Nile tilapia, they are fed a diet containing $30 \%$ protein [Siddiqut et al., 1988]. The high nitrogen and organic pollutant levels in the pond water might be caused by uneaten fish feed and fish excretions. Brune et al. [2003] reported that fish excrete approximately $36 \%$ of their input feed as organic waste. Moreover, approximately $59-75$ and $60-62 \%$ of the nitrogen $(\mathrm{N})$ and phosphorus $(\mathrm{P})$, respectively, in the excretions are released into the pond water [Brune et al., 2003, Piedrahita, 2003]. Some pollutants are toxic to fish, especially total ammonia nitrogen (TAN), which is the sum of unionized ammonia $\left(\mathrm{NH}_{3}-\mathrm{N}\right)$, and ionized ammonia $\left(\mathrm{NH}_{4}-\mathrm{N}\right)$ present in the water. $\mathrm{NH}_{3}-$ $\mathrm{N}$ is more toxic than $\mathrm{NH}_{4}-\mathrm{N}$ [Crab et al., 2007]. TAN has health impacts on Nile tilapia juveniles at a concentration of 5-10 mg/L [Hegazi et al., 2010]. The optimal $\mathrm{NH}_{3}-\mathrm{N}$ concentration for Nile tilapia is in the range of $0.01-0.004 \mathrm{mg} / \mathrm{L}$ [Sherif et al., 2008]. Thus, to control the concentrations of toxic compounds, the pond water should be withdrawn and replaced with fresh water. However, this withdrawn water is directly discarded to the receiving water, which causes eutrophication and quality deterioration in the receiving water. In a previous study, the integration of FTW and biofilters was shown to reduce TKN, TP, and BOD by approximately 82,42 , and $67 \%$, respectively [Mungkung et al., 2017]. In this study, FTW and biofilters were set up and applied in a Nile tilapia pond.

\section{Performance of the integrated FTW and Biofilter (FTW/B)}

In the control and experimental tests, the COD, BOD, TKN, $\mathrm{NH}_{4}$, ortho-P, and SS at $\mathrm{S} 6$ and $\mathrm{S} 7$ were lower than those in the other tests due to the aeration by the turbine. The concentrations of all parameters
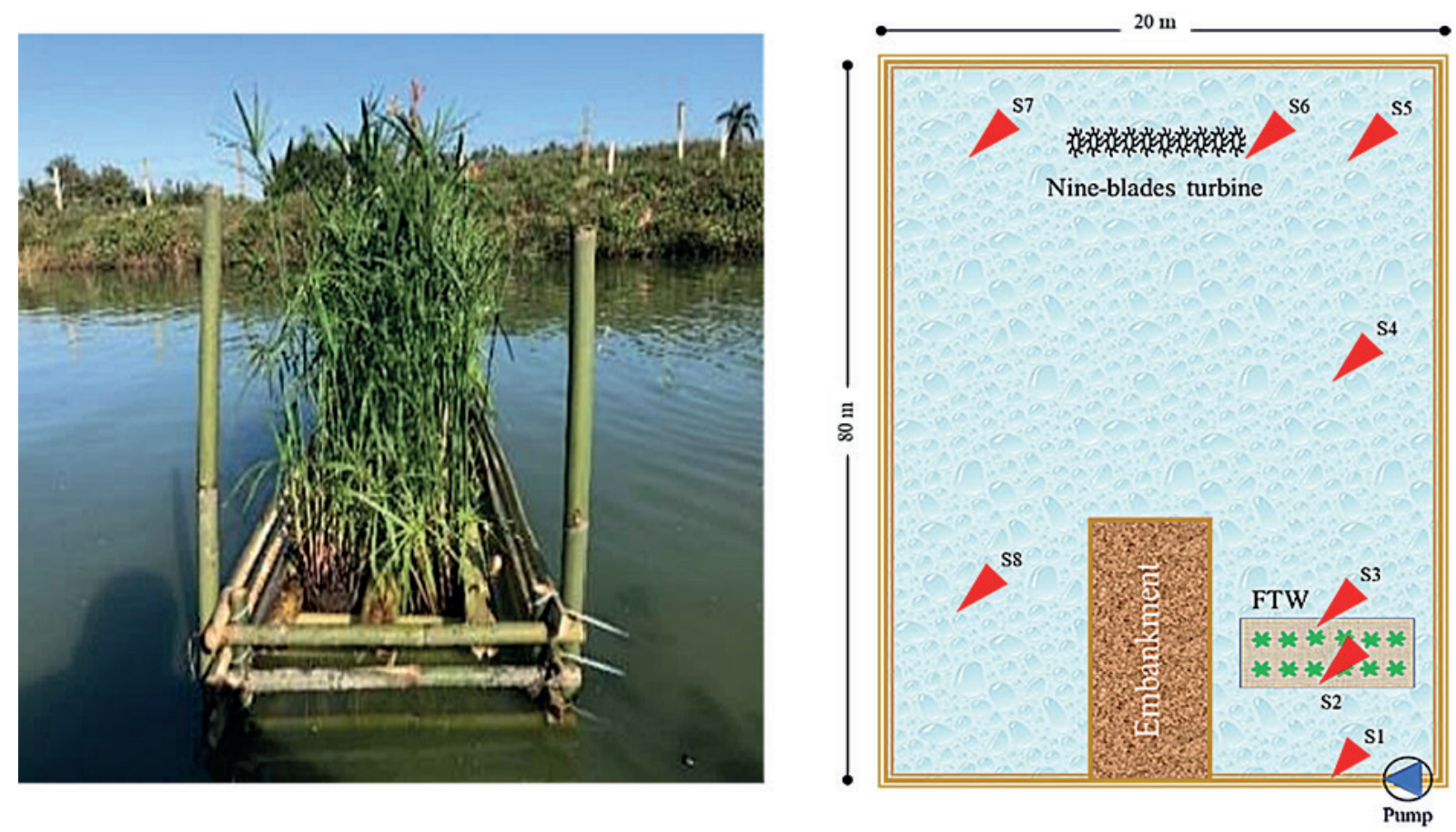

Figure 1. FTW/Bs system and water collection sites 
except ortho-P at S2 and S3 in the experimental test were lower than those in the control test.

As shown in Figure 2, the COD at all sites in the control test except S6 and S7 was in the range of $75.26-83.89 \mathrm{mg} / \mathrm{L}$. The COD at S6 and S7 was approximately $42.34-45.47$ in both tests. In the experimental test, the COD at S2 and S3 was significantly lower $(p<0.05)$ than that in the control test, by approximately $20.34-33.96 \%$. Similarly, the range of BOD was $31.80-39.00$ $\mathrm{mg} / \mathrm{L}$ at $\mathrm{S} 1$ and $\mathrm{S} 4-\mathrm{S} 8$ and $15.60-20.01 \mathrm{mg} / \mathrm{L}$ at $\mathrm{S} 2-\mathrm{S} 3$ in the control. The BOD at S2 and S3 in the experimental test was significantly lower than that in the control test, by approximately 25.47 $-29.41 \%$. The lowest COD and BOD achieved at $\mathrm{S} 2$ and $\mathrm{S} 3$ were due to the biodegradation of pollutants by the microorganisms in the biofilms attached to the plant roots and biofilters [Barco and Borin, 2020]. Some organic matter was also filtered out by the plant roots [Barco and Borin, 2020]. Moreover, the activity of microorganisms was supported and accelerated by the release of oxygen passing through the aerenchyma tissue of plants into the rhizosphere area [Pavlineri et al., 2017]. This study found that the DO at S2 and S3 was in the range of $5.30-5.50 \mathrm{mg} / \mathrm{L}$ in the experimental test, whereas $4.88-4.98 \mathrm{mg} / \mathrm{L} \mathrm{DO}$ was observed in the control test.

Figure 3 shows the variations in TKN and $\mathrm{NH}_{4}-\mathrm{N}$ in each test. A significant change $(\mathrm{P}<0.05)$ in TKN was not observed between the control and experimental tests. However, TKN declined

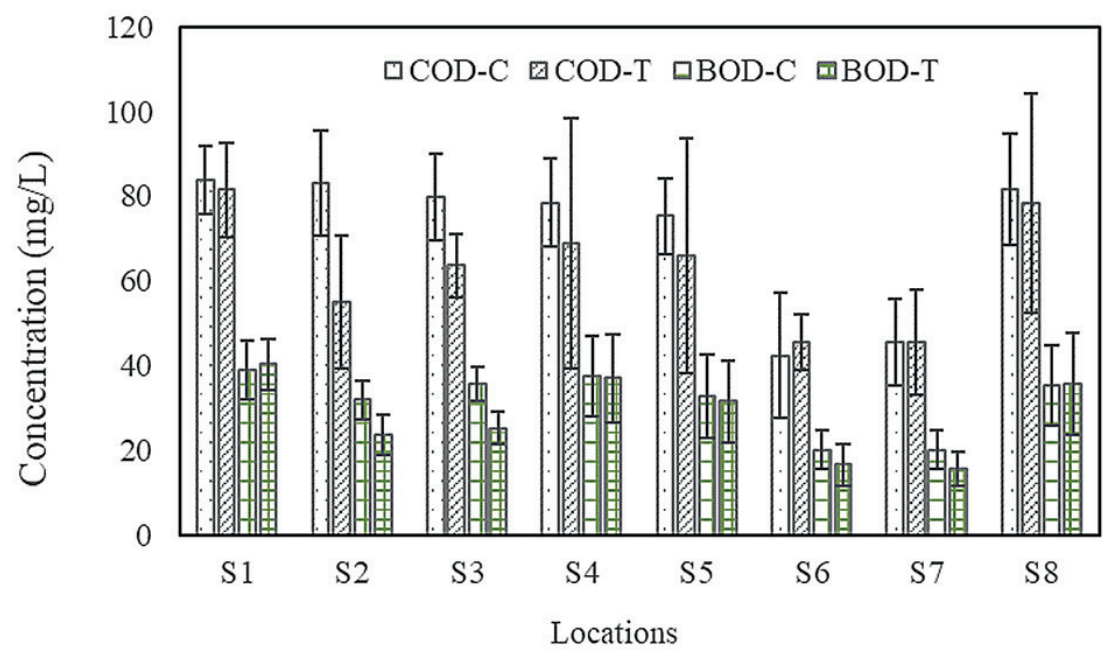

Figure 2. The changes in $\mathrm{COD}$ and $\mathrm{BOD}$ in the control $(\mathrm{C})$ and experimental test $(\mathrm{T})$. (Error bars show the standard deviation)

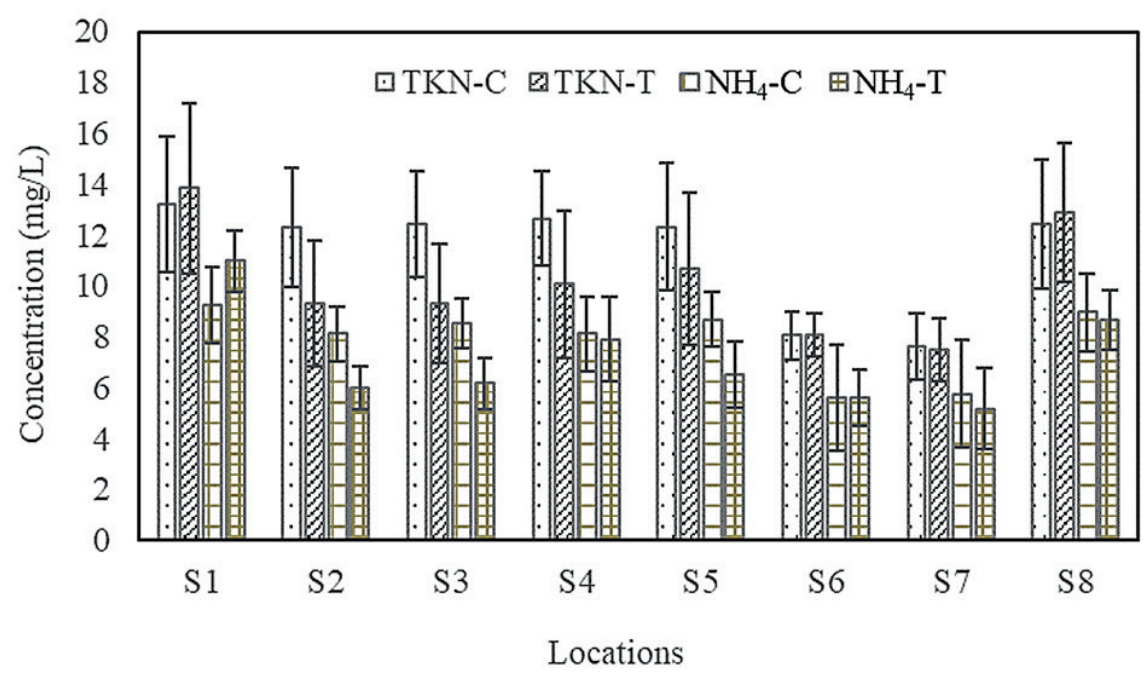

Figure 3. The changes in TKN and NH4 in the control (C) and experimental test (T). (Error bars show the standard deviation) 
at $\mathrm{S} 2, \mathrm{~S} 3, \mathrm{~S} 4$, and $\mathrm{S} 5$ in the experimental test. In addition, the $\mathrm{NH}_{4}-\mathrm{N}$ in the experimental test was significantly lower than that in the control test at S2, S3, and S5, by approximately 25.86, 27.87, and $25.00 \%$, respectively. TKN was reduced at the site near FTW/B because of the microorganismal activity and the sedimentation of organic nitrogen [Dunne et al., 2013, Zhang et al., 2014]. Ammonia nitrogen was also reduced by microbial nitrification, which was enhanced by the oxygen released from the plant roots. Wu et al. [2016] demonstrated the strong growth of aerobic heterotrophic bacteria in root zones. When a fiber filter is built under the plants in an FTW, twice as many bacteria can grow on the fiber filter as on the plant roots [Wu et al., 2016]. However, the plant nitrogen uptake was probably only a minor mechanism for $\mathrm{NH}_{4}-\mathrm{N}$ reduction. Plant harvesting can remove approximately $2-8 \%$ of the nitrogen in water. Without harvesting, the nitrogen returns to the water due to the decomposition of the plant [Langergraber, 2005].

As shown in Figure 4, no significant differences in ortho-P were observed between treatments. The ortho-P values in all tests were in the range of $0.042-0.105 \mathrm{mg} / \mathrm{L}$. FTW/B did not contribute to the reduction of phosphorus, as observed in the study of Barco and Borin [2020]. Normally, phosphorus is reduced by sorption, precipitation, and plant uptake processes [Maucieri et al., 2020]. However, the previous research has reported that approximately $79 \%$ of ortho-P is removed in FTWs by sedimentation and is further released from the sediments to the water in wetlands, with long hydraulic retention times [Chang et al., 2013,
Dunne et al., 2012]. In this study, the treatment system was placed in the fish pond for 5 weeks, and some phosphate redissolved into the water. Moreover, the previous research suggested that the phosphorus uptake by plants in FTWs did not result in a significant reduction in the phosphorus levels [Tannner and Headely, 2011, Borne, 2014].

The changes in SS in each test are shown in Figure 5. The SS at S2, S3 (near the buoyant mat), and S4 in the experimental test was significantly lower than that in the control test $(\mathrm{P}<0.05)$, by approximately $26.00,28.44$, and $21.61 \%$, respectively. The Cyperus roots grew by approximately $10 \mathrm{~cm}$ within the 5 weeks of the FTW operation. The growth of macrophytes and the dense roots under the buoyant mat were particularly effective in filters and trapped SS, as observed in the study of Pappalardo et al. [2017]. Moreover, the biofilters under the macrophytes were another mechanism for SS trapping and sedimentation.

\section{CONCLUSIONS}

The integrated FTW and biofilter significantly contributed to reducing $\mathrm{COD}, \mathrm{BOD}, \mathrm{NH}_{4}-\mathrm{N}$, and SS levels. FTW/Bs can be implemented for the treatment of aquaculture water. However, their removal efficiency depends on the macrophyte species, hydraulic retention time, and water quality. In practice, FTW/Bs should be separated from the fish culture compartment of the aquaculture pond. Moreover, the pollutant loading reduction per area by FTW/Bs remains to be determined.

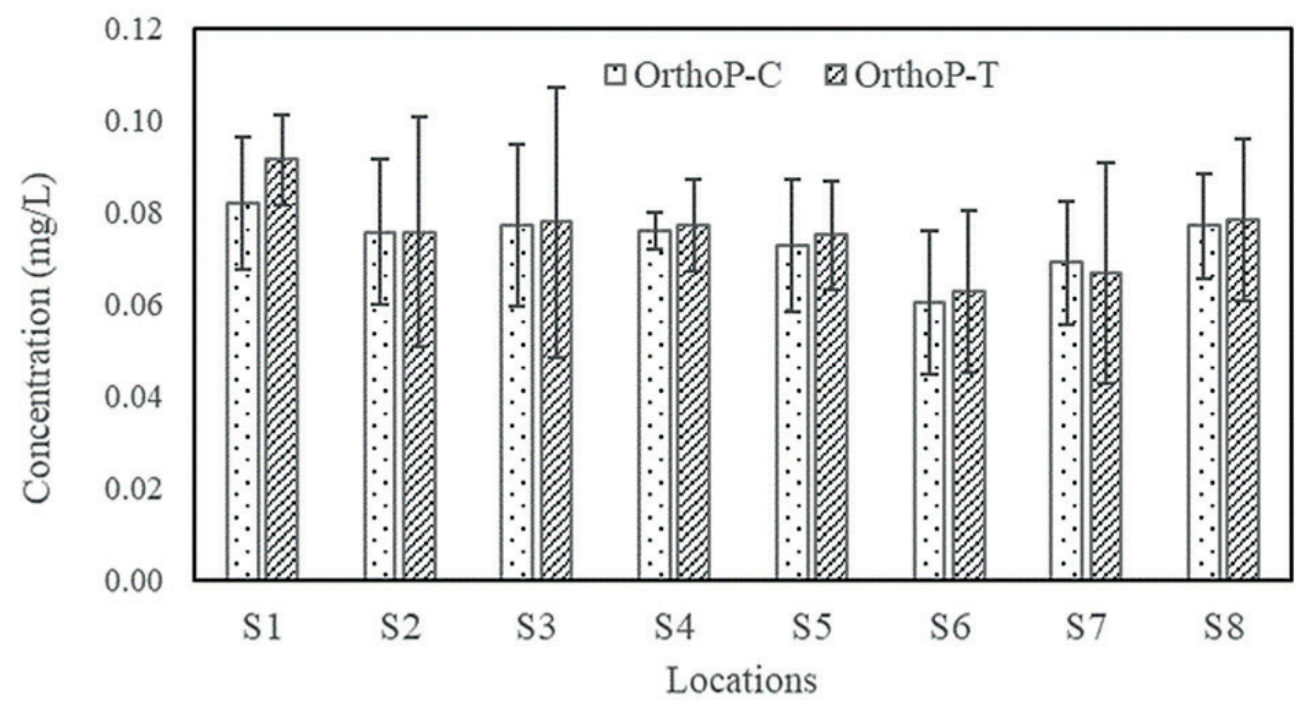

Figure 4. The changes in ortho-P in the control (C) and experimental test $(\mathrm{T})$. (Error bars show the standard deviation) 


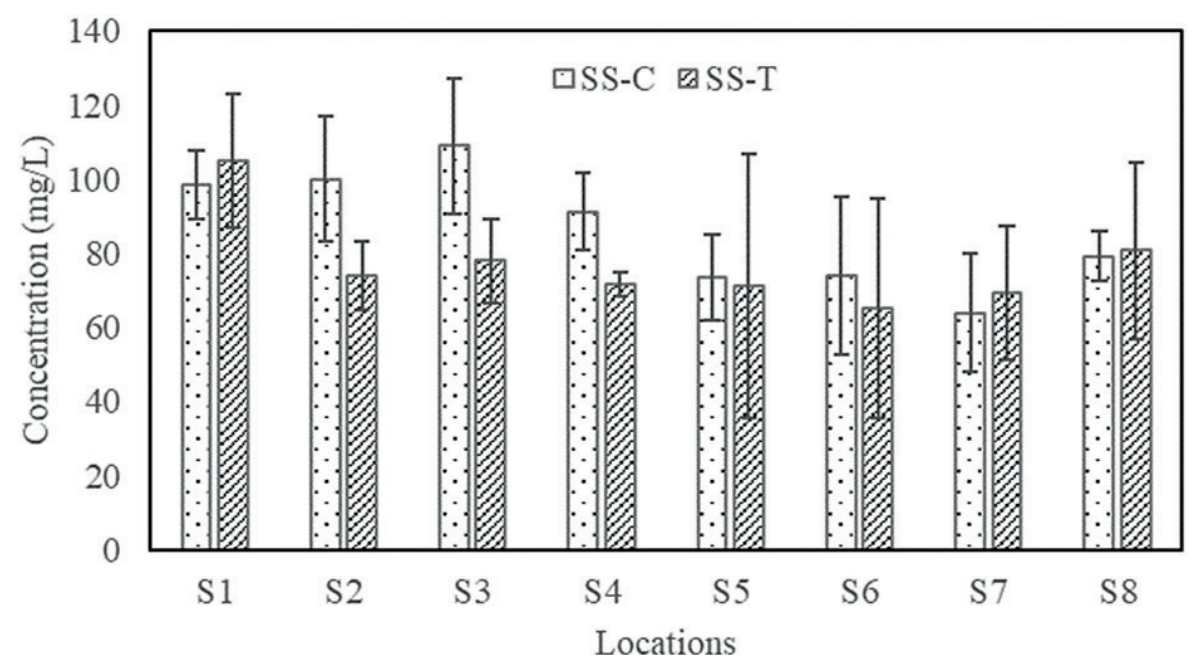

Figure 5. The changes in SS in the control (C) and experimental test (T). (Error bars show the standard deviation)

\section{Acknowledgements}

We would like to thank the Unit of Excellent Center (UOE64001), School of Energy and Environment, University of Phayao for invaluable support.

\section{REFERENCES}

1. Abed S.N., Almuktar S.A., Scholz M. 2017. Remediation of synthetic greywater in mesocosm-Scale floating treatment wetlands. Ecological Engineering, 102, 303-319.

2. APAH. 2005. Standard Methods for the Examination of Water and Wastewater, $21^{\text {st }}$ edition. American Public Health Association, American Water Works Association, Water Environment Federation, Washington, D.C.

3. Barco A., Borin M. 2020. Treatment performances of floating wetlands: A decade of studies in North Italy. Ecological Engineering, 158, 106016.

4. Benvenuti T., Hamerski F., Giacobbo A., Bernardes A.M., Zoppas-Ferreira J., Rodrigues M.A.S. 2018. Constructed floating wetland for the treatment of domestic sewage: A real-scale study. Journal of Environmental Chemical Engineering, 6, 5706-5711.

5. Bissegger S., Rodriguez M., Brisson J., Weber K.P. 2014. Catabolic profiles of microbial communities in relation to plant identity and diversity in freefloating plant treatment wetland mesocosms. Ecological Engineering, 67, 190-197.

6. Borne K.E. 2014. Floating treatment wetland influences on the fate and removal performance of phosphorus in stormwater retention ponds. Ecological Engineering, 69, 76-82.

7. Borne K.E., Fassman E.A., Tanner C.C. 2013. Floating treatment wetland retrofit to improve stormwater pond performance for suspended solids, copper and zinc. Ecological Engineering, 54, 173-182.

8. Brune D.E., Schwartz G., Eversole A.G., Collier J.A., Schwedler T.E. 2003. Intensification of pond aquaculture and high rate photosynthetic systems. Aquacultural Engineering, 28, 65-86.

9. Cao W., Wang Y., Sun L., Jiang J., Zhang Y. 2016. Removal of nitrogenous compounds from polluted river water by floating constructed wetland using rice straw and ceramsite as substrates under low temperature condition. Ecological Engineering, 88, 77-81.

10. Castro-Castello A.T., Chipps M.J., Hankins N.P., Hughes J.M.R. 2016. Lessons from the "Living-Filter": An in-reservoir floating treatment wetland for phytoplankton reduction prior to a water treatment works intake. Ecological Engineering, 95, 839-851.

11. Chang N.B., Xuan Z., Marimon Z., Islam K., Wanielista M.P. 2013. Exploring hydro biogeochemical processes of floating treatment wetlands in a subtropical stormwater wet detention pond. Ecological Engineering, 54, 66-76.

12. Crab R., Avnimelech Y., Defoirdt T., Bossier P., Verstraete W. 2007. Nitrogen removal techniques in aquaculture for a sustainable production. Aquaculture, 270, 1-14.

13. Dunne E.J., Coveney M.F., Marzolf E.R., Hoge V.R., Conrow R., Naleway R., Lowe E.F., Battoe L.E. 2012. Efficacy of a large-scale constructed wetland to remove phosphorus and suspended solids from Lake Apopka, Florida. Ecological Engineering, 42, 90-100.

14. Dunne E.J., Coveney M.F., Marzolf E.R., Hoge V.R., Conrow R., Naleway R., Low E.F., Battoe L.E., Inglett P.W. 2013. Nitrogen dynamics of a large-scale contructed wetland used to remove excess nitrogen from eutrophic lake water. Ecological Engineering, 61, 224-234. 
15. El-Sherif M.S., El-Feky A.M. 2008. Effect of ammonia on Nile tilapia (O. niloticus) performance and some hematological and histological measures. The $8^{\text {th }}$ International Symposium on Tilapia in Aquaculture. 513-530.

16. FAO. 2020. The state of world fisheries and aquaculture sustainability in action.

17. Hegazi M.M., Attia Z.I., Ashour O.A. 2010. Oxidative stress and antioxidant enzymes in liver and white muscle of Nile tilapia juveniles in chronic ammonia exposure. Aquatic Toxicology, 99, 118-125.

18. Langergraber G. 2005. The role of plant uptake on the removal of organic matter and nutrients in subsurface flow constructed wetlands: a simulation study. Water Science and Technology, 51, 213-223.

19. Lopardo C.R., Zhang L., Mitsch W.J., Urakawa H. 2019. Comparison of nutrient retention efficiency between vertical-flow and floating treatment wetland mesocosms with and without biodegradable plastic. Ecological Engineering, 131, 120-130.

20. Maucieri C., Salvato M., Borin M. 2020. Vegetation contribution on phosphorus removal in wetland microcosms. Ecological Engineering, 152, 105853.

21. Mungkung S., Homklin S., Somprasert S. 2016. The removal of nutrients in water from Nile tilapia fishery farm by floating constructed wetland system with biological filters. The $16^{\text {th }}$ National Environmental Conference, 11-12.

22. Pappalardo S.E., Ibrahim H.M.S., Cerinato S., Borin M. 2017. Assessing the water purification service in an integrated agricultural wetland within the venetian Lagoon drainage system. Marine and Freshwater Research, 68, 2205-2215.

23. Pavlineri N., Shoulikidis N.T., Tsihrintzis V.A. 2017. Constructed floating wetlands: a review of research, design, operation and management aspects, and data meta-analysis. Chemical Engineering Journal, 308, 1120-1132.

24. Piedrahita R.H. 2003. Reducing the potential environmental impact of tank aquaculture effluents through intensification and recirculation. Aquaculture, 226, 35-44.
25. Saeed T., Al-Muyeed A., Afrin R., Rahman H., Guangzhi S. 2014. Pollutant removal from municipal wastewater employing baffled subsurface flow and integrated surface flow-floating treatment wetlands. Journal of Environmental Sciences, 26, 726-736.

26. Shahid M.J., Arslan M., Siddque M., Ali S., Tahseen R., Afzal M. 2019. Potentialities of floating wetlands for the treatment of polluted water of river Ravi, Pakistan. Ecological Engineering, 133, 167-176.

27. Siddiqut A.Q., Howlader M.S., Adam A.A. 1988. Effects of dietary protein levels on growth, feed conversion and protein utilization in fry and young Nile tilapia, Oreochromis niloticus. Aquaculture, 70, 63-73.

28. Tanner C.C., Headley T.R. 2011. Components of floating emergent macrophyte treatment wetlands influencing removal of stormwater pollutants. Ecological Engineering, 37, 474-486.

29. Tharp R., Westhelle K., Hurley S. 2019. Macrophyte performance in floating treatment wetlands on a suburban stormwater pond: Implications for cold climate condition. Ecological Engineering. 136 (2019) 152-159.

30. Wang C.Y., Sample D.J., Bell C. 2014. Vegetation effects on floating treatment wetland nutrient removal and harvesting strategies in urban stormwater ponds. Science of the Total Environment, 499, 384-393.

31. White S.A., Cousins M. 2013. Floating treatment wetland aided remediation of nitrogen and phosphorus from simulated stormwater runoff. Ecological Engineering, 61, 207-215.

32. Wu H., Zhang J., Ngo H.H., Guo W., Hu Z., Liang S., Fan J., Liu H. 2015. A review on the sustainability of constructed wetlands for wastewater treatment: Design and operation. Bioresource Technology, 175, 594-601.

33. Wu Q., Hu Y., Li S., Peng S., Zhao H. 2016. Microbial mechanisms of using enhanced ecological floating beds for eutrophic water improvement. Bioresource Technology, 211, 451-456.

34. Zhang C.B., Liu W.L., Pan X.C., Guan M., Liu S.Y., Ge Y., Chang J. 2014. Comparison of effects of plant and biofilm bacterial community parameters on removal performances of pollutants in floating island systems. Ecological Engineering, 73, 58-63. 